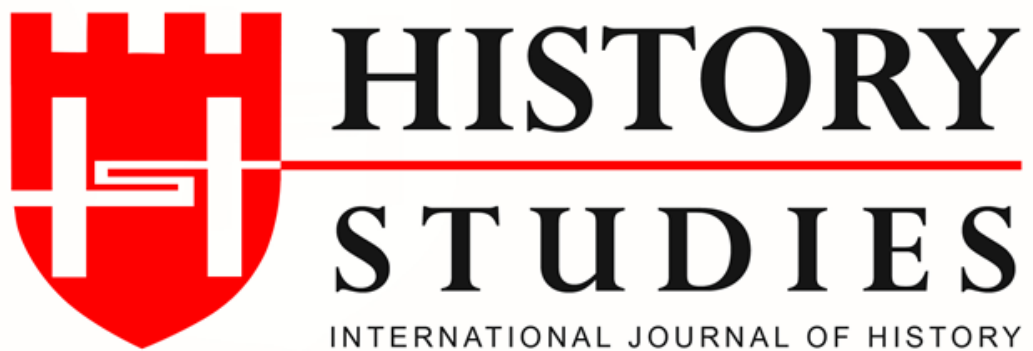

ISSN: 13094173 / (Online) 1309 - 4688 (Print)

Volume: 13, Issue: 4, August 2021

www.historystudies.net

THE KNOWLEDGE PRODUCTION FROM ANKARA TO

INEBOLU: SOCIO-ECONOMIC, ANTHROPOLOGICAL AND POLITICAL OBSERVATIONS OVER THE BRITISH AGENT'S TRAVEL IN 1905

Ankara'dan Inebolu'ya Bilgi Üretimi: Bir Ingiliz, Ajanının 1905 'teki Seyahati üzerinden Sosyo-Ekonomik, Antropolojik ve Siyasi Gözlemler

Arş. Gör. Özge Aslanmirza

Kocaeli Üniversitesi ozge.aslanmirza@kocaeli.edu.tr ORCID ID: 0000-0001-9664-9880

Makale Türü-Article Type Geliș Tarihi-Received Date Kabul Tarihi-Accepted Date DOI Number
Araştırma Makalesi-Research Article 21.05.2021

13.08.2021

10.9737/hist.2021.1025

Atıf-Citation:

Özge Aslanmirza, “The Knowledge Production From Ankara to Inebolu: Socio-Economic, Anthropological and Political Observations Over The British Agent's Travel in 1905", History Studies, 13/4, Ağustos 2021, s. 1061-1077.

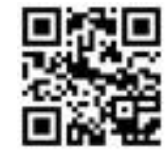



HISTORY STUDIES

Uluslararası Tarih Araştırmaları Dergisi International Journal of History 13/4, Ağustos - August 2021

1061-1077

Araştırma Makalesi

\section{THE KNOWLEDGE PRODUCTION FROM ANKARA TO INEBOLU: SOCIO-ECONOMIC, ANTHROPOLOGICAL AND POLITICAL OBSERVATIONS OVER THE BRITISH AGENT'S TRAVEL IN 1905}

Ankara'dan Inebolu'ya Bilgi Üretimi: Bir İngiliz Ajanının 1905'teki Seyahati üzerinden SosyoEkonomik, Antropolojik ve Siyasi Gözlemler

\section{Arş. Gör. Özge Aslanmirza}

\section{$\ddot{O} \mathbf{z}$}

Orta Doğu'daki sömürgelerini kontrol altında tutma ve bu bölgedeki çıkarlarını koruma düşüncesi İngiltere'nin başlıca gayesi olmuştur. Orta Doğu üzerine üretilen her bilgi değerli görülmüşsür. Emperyalist politikaların meşru zemini, üretilen bilginin siyasi ve ekonomik politikaların şekillenmesiyle oluşturulmuştur. Bilgi üretme kanallarının en önemli kurumları bölge üzerine arkeolojik, tarihi ve etnografik araștırmalar yapan kurumlar olurken, bilgi akışını sağlayanlar da Orta Doğu'ya giden ve gönderilen ajanlar olmuşlardır. Orta Doğu üzerinde bilgi üretimini seyahatleri üzerinden gerçekleştiren ajanlardan biri de, Sykes-Picot antlaşmasının mimarlarından Mark Sykes'tır. Bu çalışma da, İngiltere'nin emperyalizm politikasının somut bir yansıması olarak görülen, Mark Sykes'ın 1905 y1lında Orta Doğu'da gerçekleştirdiği seyahatinde tuttuğu notlarına odaklanacaktır. Sykes'ın bu gezisinde, çıkardığ1 insan tipolojisi oryantalist bağlamda Batı üstünlüğünün bir yansıması olarak oluşur. Ayrıca, istihbarati bir faaliyet gerçekleştirmiş olan Sykes'ın izlediği rota boyunca politik ve antropolojik gözlemlerini ortaya koyarak 20. yüzyılın başlarında bilgi üretiminin ne derece önem arz ettiğini ve Sykes'ın İngiliz-Osmanlı politikası üzerine fikirlerini de ortaya koymaktadır. Dolayısıyla bu çalışma, İngiltere'nin Orta Doğu üzerindeki bilgi üretimini, Mark Sykes'ın seyahati üzerinden, antropolojik irdelemelerin ve sosyoekonomik gelişimlerin İngiltere'nin oryantalist ve emperyalist bağlamında ne anlam ifade ettiğini inceleyecektir

Anahtar Kelimeler: Mark Sykes, Oryantalizm, İngiliz Emperyalizmi, Seyahat, İngiliz-Osmanlı İlişkileri, Orta Doğu
The fundamental purpose of Britain was to control his colonies in the Middle East and protect his interests in the regions at the end of the $19^{\text {th }}$ and the beginning of the $20^{\text {th }}$ centuries. Thus, all knowledge production activity was valuable. The legitimate ground of the imperialist policies was formed by the knowledge production through which political and economic policies emerged. The salient channels of knowledge production became the societies and the institutions conducting archaeological, historical, and ethnographic studies and the agents were the providers of information flow related to the Middle East. One of the agents with this mission was Mary Sykes, who was one of the signatories of the SykesPicot Agreement. Thus, research will focus on Mark Sykes's travel, in which he visited Ankara and Inebolu in 1905, as a reflection of Britain's imperialist policy. His categorization of people was the projection of Western superiority in the orientalist context. In addition, Sykes exposed his political and anthropological observations in the scope of intelligence gathering. He also reveals his thoughts on Anglo-Ottoman relations. Thus, this study will examine the knowledge production of Britain in the Middle East over the travel of Mark Sykes and reveal the significance of anthropological inspections and socio-economic developments in Britain's orientalist and imperialist context.

Keywords: Mark Sykes, Orientalism, British Imperialism, Travelling, Anglo-Ottoman relations, the Middle East 


\title{
Introduction
}

The $19^{\text {th }}$ and the early $20^{\text {th }}$ century is the period when the most complicated patterns of change came together along with the products in different disciplines. The scientific developments highly developed while the competition among the states gained momentum in terms of economy. The colonization began to occur as a means of occupation of new territories and benefitting from their sources. Afterward, imperialism became a conceptual apparatus and a policy for protecting the state interest and civilizing the other -the East- in the sight of the West. In this direction, a new world order ensued in which the sources of the colonies were exploited, and the cultures of colonies were transformed. In this kind of order, imperialist policies commenced having a legitimate ground over the dialectics such as civilized-uncivilized and superior-inferior. Fundamentally based on the distinction between the East and the West, this distinction made the East "other" in the image of the West which constructed the East as an exotic, barbarian, and uncivilized object. Besides, the West aspired to identify and know the East by certain interests. Thus, this motivation generated a variety of knowledge production channels. Particularly, agent-travelers vastly contributed to the knowledge production of England through their investigations and findings with their identities such as archaeologists, anthropologists, and historians. In this context, Mark Sykes was one of the agents who contributed to the knowledge production and had an impact on the English policy in the Middle East by the well-known Sykes-Picot Agreement. He visited almost all the corners of the Middle East, had contact with local people and tribes, conducted archaeological and anthropological studies. Hence, he became an expert in the Middle East in terms of his political career. All in all, the purpose of this study is to display the socio-economic, anthropological, and political observations and locate their role in the imperialistic agenda of British politics. Thus, this analysis will help to reveal the knowledge production of Britain in the Middle East over the travel of Mark Sykes in 1905.

\section{Britain's Need for the Middle East Knowledge}

There is a requirement for a synopsis related to the developments between Britain and the Ottoman Empire to contextualize the travel of Mark Sykes and to locate his knowledge production concerning the Middle East. Particularly in the first half of the $19^{\text {th }}$ century, Britain adopted a policy of supporting and protecting Ottoman integrity. ${ }^{1}$ However, this policy was altered due to the changing balance of power in the second half of the $19^{\text {th }}$ century. Britain aimed at protecting Indian trade routes with the opening of the Suez Channel in 1869 while Russia followed a policy of encouraging the Balkan nations to uprise on the ground of religious protection. ${ }^{2}$ In addition, Russia aspired to leave Ottoman Empire alone by getting Europe onside. Besides, Gladstone, who was the liberal Prime Minister in the 1880s, came to power adhering to anti-Turkish policies. ${ }^{3}$ Gladstone was the political projection of the orientalist perspective. For example, he used the Bulgarian Revolt in 1876 to prompt the downfall of the government

\footnotetext{
${ }^{1}$ For the policies of the British Prime Ministers as to Ottoman Empire see David Steele, "Three British Prime Ministers and the Survival of the Ottoman Empire, 1855-1902," Middle Eastern Studies 50:1 (2014): 43-4; Frank Edgar Bailey, British Policy and Turkish Reform Movement: A Study of Anglo-Turkish Relations, 1826-1953 (Cambridge: Harvard University Press, 1942): 129-178; Paul R. Ziegler, Palmerston (British History in Perspective) (New York: Palgrave Macmillan, 2003): 48-50. There were diverse fractions among the Ottoman bureaucrats as to the policies in the international arena. For the related discussions see Ali Fuat Türkgeldi, Maruf Simalar, eds. Mehmet Kalpaklı \& Sina Akşin Somel (Ankara: Türk Tarih Kurumu, 2013).

${ }^{2}$ Fahriye Begüm Yıldızeli, "The Expansion of the British Empire in the Middle East After the Ottoman Heritage (18821923)," History Studies 10: 6 (2018): 217.

${ }^{3}$ For a recent study about the transformation of Anglo-Ottoman relations see Taha Niyazi Karaca, "Dostluktan Çatışmaya: Osmanlı Dönemi Türk-İngiliz İlişkileri,” Journal of Anglo-Turkish Relations 1:1 (2020): 11-32.
}

\author{
History Studies \\ www.historystudies.net
}


of Disraeli, who followed Turcophile policies in his presidency, by asserting that the Ottoman government massacred Bulgarians to suppress the revolt. ${ }^{4}$ Even, Gladstone published a pamphlet called Bulgarian Horrors and the Question of the East (1876) in which he accused Turks of being "great anti-human specimen of humanity" and wherever they set foot in, they left the mark of blood. ${ }^{5}$

The demand of Britain to dominate different regions was fundamentally political and economic. This required a certain approach and the process of knowledge production towards the people and the region. The developments such as territorial gains of Russia from the Ottoman Empire and the aim of France in the Middle East caused Britain to initiate strategies and gave priority to intelligence-gathering. ${ }^{6}$ Besides, in the $19^{\text {th }}$ century, developing and accelerating transportation facilities, such as intercontinental journeys of steamships and the extension of railways, increased mobility. Therefore, traveling began to be an apparatus of knowledge production by being deemed as a vanguard of the unknown. Hence, traveling ostensibly distinguished the East and the West. Thus, the discourse of superiority of the West over the East strengthened. Because the literature concerning travel indicated a transformation in which "the West constructed itself as a hegemonic subject." Apart from that, the concept of civilization was another legitimization tool of Britain's domination. Relatedly, the prevalent discussion on orientalism should be underlined, as the $19^{\text {th }}$ century was the period when the distinction of civilized and uncivilized became much more apparent. Besides, the colonialist mentality institutionalized the knowledge production channels in an orientalist way. The West regarded the East as "other" and the representation of a fictional phantasy. The East was imaginative geography because the East had undeveloped and stable structures vis-à-vis the West. The fictional texts fed the perception of the East, as a result, the East was weak and depleted, though, it was a chamber of the exotic and pleasant world of delusion. If the East had aspired to develop and civilize, it could only have happened with the help of external assistance. Yet, when this transformation was realized, the East would be a colony, or it would be a mandated territory in which its freedom was constrained or lost.

The approach of the West established a legitimate basis for possession of the rich sources and the desire of colonization in the Middle East by knowledge production about the region highlighting the East and the West dichotomy at the $18^{\text {th }}$ and $19^{\text {th }}$ centuries. This led to identify the East and have the knowledge of its culture. ${ }^{8}$ The approach of the West, which was adumbrated elsewhere, provided a coherent context for the mental and political atmosphere of the $19^{\text {th }}$ and $20^{\text {th }}$ centuries. Considering the situation of the Ottoman Empire, Britain supported the survival of the Ottoman Empire at first; however, this purpose turned into a policy of dividing the Middle Eastern lands of the Ottoman Empire. The desire of knowing the Middle East implied the systematic knowledge production as to this region along with the institutionalization of knowledge production. For this reason, agents, ambassadors, travelers, and missionaries frequently traveled there. A plethora of institutions and societies were

\footnotetext{
${ }^{4}$ Yahya Bağçeci, “İngiltere Parlamento Tutanaklarında 1876 Bulgar İsyanı”, International Journal of Social Science 24 (2014): 225-229.

${ }^{5}$ William Ewart Gladstone, Bulgarian Horrors, and the Question of the East (New York \& Montreal: Lovell, Adam, Wesson \& Company, 1876): 10.

${ }^{6}$ Sara El Gaddari, "Hanmer Warrington and Imperial intelligence-gathering in Tripoli," in Diplomacy and Intelligence in the Nineteenth-Century Mediterranean World, eds. Mika Suonpää and Owain Wright (London: Bloombury Publishing, 2019): 39.

7 İbrahim Şirin, "Seyahatnâmelerin Sosyal Bilimlerde Kullanım Değeri: Seyahatnâme Metodolojisi Geliştirmenin Zorunluluğu", in Yabancı Seyahatnamelerde Türkiye, eds. M. Çağatay Özdemir \& Yunus Emre Tekinsoy (Ankara: Türk Yurdu Yayınları, 2016): 12.

${ }^{8}$ Recep Boztemur, "Marx, Doğu Sorunu ve Oryantalizm," Oryantalizm I (Ankara, Doğu Batı Yayınları, 2002): 135.
}

\author{
History Studies \\ www.historystudies.net
}


established for similar purposes as of the $18^{\text {th }}$ century. ${ }^{9}$ They were the precursors of the intelligence bureaus, which commenced to have been systematized in the early $20^{\text {th }}$ century, such as the Arabian Bureau. ${ }^{10}$ As the target of the knowledge production in intelligence was to know the other, develop expert knowledge about the target and garner reliable evidence from all sources, these institutions and societies already stood for these objectives. ${ }^{11}$ In this respect, anthropology as a freshly institutionalized discipline was used for knowledge production as a political apparatus. The discipline of anthropology, which was the product of the Enlightenment Era, rendered the knowledge related to human by inspecting the productions of human and societies in which the human exists. ${ }^{12}$ That's why it was presumably one of the most significant research fields in terms of intelligence gathering. Thus, to know the people and to create their profiles specific to the Middle East were facilitators for establishing dominance while it provided penetration to the mentality of geography being considered as other.

\title{
2. From Ankara to Inebolu
}

Mark Sykes is one of the signatories of the Sykes-Picot Agreement known by the division of the Middle East among the states such as France and Britain. He traveled with his father in many places around the world since his childhood. These travels particularly the ones in the Middle East enabled him to be interested in the geography and the people of the Middle East. ${ }^{13}$ The deep-rooted past of his aristocrat family, who was involved in trade, military, and politics, provided him with a natural educational environment at home, although his formal educational life was an undulant one. He got home-schooling for a while and then he attended Beaumont College and St Louis College. He started Cambridge University; however, he did not complete his university education. After two years in university, he enrolled in the Yorkshire Regiment and went to South Africa for joining the Second Boer War. ${ }^{14}$ He took the first steps for his political career in the ensuing years after the war. George Wyndham, who was the Chief Secretary to Ireland, offered him to be his Private Secretary. Mark Sykes accepted this position and became his Private Secretary from 1904 to $1905 .{ }^{15}$ Yet, this position did not make him contented. In a letter to his wife, he stated that he hated politics and he needed a real job rather than being stuck in an office. ${ }^{16} \mathrm{He}$ aspired to have a career in which he would be able to display his knowledge about the Middle East. ${ }^{17}$ The opportunity came because of his constant pursuit

\footnotetext{
${ }^{9}$ Certain societies and institutions on knowledge production related to the Middle East are: Asiatic Society of Bengal adını alan Asiatick Society (Asiatic Society of Bengal) established in 1784 at Bengal, Ecole des Langues Orientales Vivantes founded in 1795 at Paris, Institut d'Egypte in 1789 at Egypt, Société Asiatique in 1822 at France, Royal Asiatic Society (full name: Royal Asiatic Society of Great Britain and Ireland) in 1823 at England and Deutsche Morgenländische Gesellschaft in 1845 at Germany, etc. Palestine Exploration Fund was opened in 1865. Many institutions politically benefitted from the knowledge production and they led to foster intelligence system in the Middle East.

${ }^{10}$ As indicated on the website of the Secret Service Bureau (MI6), the British government regarded Germany as a threat in the early 1900s for their integrity due to Germany's imperialist desires. When the stories about the German agents became prevalent, the Director of Military Operations began to think that Germany targeted Britain. Although rumors were exaggerated, Prime Minister Herbert Asquith ordered Imperial Defence Committee to examine the matter and Secret Service Bureau was opened in July 1909. “Our History: Beginnings 1909," Secret Intelligence Service MI6, accessed May 1, 2021, https://www.sis.gov.uk/our-history.html.

${ }^{11}$ Michael Herman, "Why Does Military Intelligence Matter?”, Changing Character of War Seminar, Oxford, accessed May 1, 2021, http://www.nuffield.ox.ac.uk/OIG2/herman\%20 paper\%202007.pdf4.

${ }^{12}$ Claude Levi-Strauss, “Antropoloji”, trans. Ümit Meriç, Sosyoloji Konferansı Dergisi 16 (1978): 127.

${ }^{13} \mathrm{He}$ was followed by the Ottoman government beginning from his first visit to the Middle East. For the related document, see BOA, (Prime Ministry Ottoman Archives), Dahiliye Nezareti, Şifre Kalemi Belgeleri, DH. ŞFR., (DH. ŞFR.), 223/ 87, 13 Eylül 1897, (1315. R. 01).

${ }^{14}$ Christopher Simon Sykes, A Man Who Created the Middle East: A Story of Empire, Conflict, and the Sykes-Picot Agreement (Londra: William Collins Books, 2016): 77.

${ }^{15}$ Simon Sykes, A Man Who Created, 122.

${ }^{16}$ Shane Leslie, Mark Sykes: His Life and Letters (Londra: Cassell 1923):102-3.

${ }^{17}$ Roger Adelson, Portrait of an Amateur (London: Jonathan Cape, 1975): 106.
}

\author{
History Studies \\ www.historystudies.net
}


and his wife's notice to her brother, who was then an Under-Secretary in the Foreign Office. Sykes was offered a position as an honorary attaché at the British Embassy in Istanbul. ${ }^{18} \mathrm{He}$ stayed in that position till 1906. Afterward, he became the Member of Parliament in Central Hull in 1911. He participated in the De Bunsen Committee where the future of the policy regarding the Ottoman Empire was negotiated. Lastly, he served as an advisor to the Foreign Office until he died in 1919.

Each of his travels aimed to contribute to Britain's knowledge production in the Middle East. Before his travel in 1905, he went to the Middle East several times and he also got some of their travel notes published. ${ }^{19}$ His position was honorary attaché at Istanbul when he traveled from Ankara to Inebolu in 1905. As his position enabled him to conduct fieldwork, he concentrated his activities and travels on intelligence gathering. That was salient for him considering the Anglo-Ottoman relations. At the beginning of the $20^{\text {th }}$ century, the Ottoman Empire became a diplomatic tool for the states such as Britain and France to balance the political power in the world and acted together with Germany in several issues as the Ottoman government regarded Germany as a redeemer. For example, the Ottoman Empire permitted Baghdad Railway construction to Germany for fear of losing control of the Mesopotamian railway to the control of Britain. ${ }^{20}$ Moreover, the Ottoman soldiers were trained by German commanders. Mark Sykes believed that Britain should have sustained and supported the Ottoman Empire both against the mutual enemy of them, Russia, and also Britain should have stood by the Ottoman Empire against Germany to protect British supremacy. As Sykes was aware that Germans were also seeking petroleum sources in the Middle East, he decided to start the examinations on petrol in the region with the permission of Nicholas O'Conor, the British Ambassador to Turkey at that time.$^{21} \mathrm{He}$ traveled to the territories such as Baghdad, Mosul, and Bitlis in which he mapped the petroleum regions with the help of the notes that he acquired from a German engineer. ${ }^{22}$ O'Conor sent the detailed maps and pictures to the Secretary of State for Foreign Affairs, Henry Fitzmaurice, with a note in which he assured that Sykes, "traveling to the rarely visited part of Asia", prepared a successful report. ${ }^{23}$

As understood from the date of archival sources, Sykes embarked on his travel from Ankara to Inebolu after his field trip for petroleum. His travel notes in 1905 in which he wrote the "unexplored places" are analyzed under three categories considering the intensity of the observation in certain topics: socio-economic observations, anthropological observations, and political observations. The integrity of the three categories demonstrates the points that he found salient to convey to the Foreign Office in terms of intelligence gathering. Also, they exemplify Mark Sykes' perception of the Middle East.

\title{
2.1. Socio-Economic Observation of Sykes from Ankara to Inebolu
}

Mark Sykes gives wide place to social and economic developments during his travel. His observations and comments as to regions' productivity and industrial infrastructure are

\footnotetext{
${ }^{18}$ Simon Sykes, A Man Who Created, 144.

19 The main works of Mark Sykes related to the Middle East are Through Five Turkish Provinces, Dar-ul-Islam: A Record of a Journey Through Ten of the Asiatic Provinces of Turkey, The Caliphs' Last Heritage: A Short History of the Turkish Empire.

${ }^{20}$ Cenk Reyhan, “Türk-Alman İlişkilerinin Tarihsel Arka Planı (1878-1914),” Belleten 69: 254 (2005): 250.

${ }^{21}$ Simon Sykes, A Man Who Created, 149. Sykes sent the report titled Report on the Petroliferous Districts of the Vilayets of Baghdad, Mosul, and Bitlis to ambassador O'Conor. Afterward, O'Conor sent the report to Foreign Office with the notice of "confidential" on 15 October 1905. TNA, (The National Archives) PRO, FO 78/5398, 13-22; Ian Rutledge, Enemy on the Euphrates: the British occupation of Iraq and the Great Arab Revolt, 1914-1921 (London: Saqi Books, 2014): 5-9.

${ }_{22}$ PRO, FO 78/5398, 17; PRO, FO 78/5398, 381. Unfortunately, there is no further detail about who this German engineer was and why he helped Mark Sykes related to petroleum districts.

${ }^{23}$ PRO, FO 78/5398, 367.
}

\author{
History Studies \\ www.historystudies.net
}


highlighted in his travel notes. As understood from his notes, he paid attention to diverse aspect of the society and the regions facilities from prevalent diseases to tourism potential of the region by emphasizing its economic potential. The reason for his intense observations lies in the social and economic developments of the era. When the Ottoman State was unable to pay the external debts in 1876, Europe found a new method to guarantee the discharge of debt. They established a control mechanism of which the tax sources of the Ottoman State were controlled, and the income was directly transferred to creditor states. ${ }^{24}$ The establishment of the Ottoman Public Debt Administration provided regular payment to Western states at the end of the $19^{\text {th }}$ century; however, financial problems in Ottoman State were exacerbated until World War I. Thus, the Ottoman government had to levy high taxes on people. This situation led to uprisings in different regions. ${ }^{25}$ Accordingly, Mark Sykes wrote detailed comments as to the economics in the Ottoman Empire in a period when she was in financial trouble. This manifests that Sykes aspired to present an Ottoman Empire who was striving to fix her image. Because Sykes considered the Ottoman Empire significant in terms of British policies, he thought that Britain would not abandon the policy of protecting the Ottoman Empire. Even, in an undated draft letter to the King of Britain, he wrote that he was visiting the Middle East since he was seven years old and he thoroughly knew the sources, geography, and the people. He added if Britain did not protect the integrity of the Ottoman Empire, she would be dismantled among other forces and the ramifications would be abhorrent. ${ }^{26}$ Thus, evaluation of the social and economic aspects in the context enables us to grasp the significance of travel.

Starting his journey from Ankara, Mark Sykes particularly dwelled on economic activities and he examined reports related to the region before as understood from his notes. He took notes on population, the yield of the land, and methods of cultivation. For example, he expressed that the Bezirgan ${ }^{27}$ the village, having 350 houses, was a marketplace for the surrounding settlements. In addition, as the district governor lived there, the village grew both in size and importance. ${ }^{28}$ Sykes added that the population was highly affected by the disease (syphilis) which was emerged twenty-five years ago and the disease spread from southern parts of the region to the coast of the Black Sea like an epidemic. ${ }^{29} \mathrm{He}$ observed that the disease posed threat to people between the age of forty-five and fifty while elder and younger people were hardly appeared to have been affected by looking at their appearance. He added that people still had traces of disease as most of the people had "sunken noses" and "distorted fingers". ${ }^{30}$ On a separate note, he mentioned progress compared to the past and the medical staff kept control of the disease. Yet, although Sykes claimed that medical staff did not have trouble in persuading

\footnotetext{
${ }^{24}$ Şevket Pamuk, Osmanll-Türkiye İktisadi Tarihi 1500-1914 (Istanbul: İletişim Yayınları, 2007): 232.

25 Nadir Özbek, Imparatorluğun Bedeli: Osmanlı Imparatorluğu'nda Gelir Vergisi 1839-1908 (Istanbul: Boğaziçi Üniversitesi Yayınevi, 2015): 113-154.

${ }^{26}$ Turkish Historical Foundation, Microfilm Archive (from Hull University Archive), The papers of Sir Mark Sykes, 1879- 1919 [microform]: with special reference to the Sykes-Picot Agreement and the Middle East, Microfilm 2, DDSY2/4 Foreign Affairs and Travel (1888-1919), 4/45 not dated, Draft Letter to 'Your Highness' from Mark Sykes about the condition of Turkey following the war with the Balkan Allies, with suggestions for improvement pp. 4-5 (pages of microfilm number in image).

27 Bezirgan. As understood from the notes of Mark Sykes, Bezirgan is the village in Kastamonu in the North of Ankara/Karaviran.

${ }^{28} \mathrm{PRO}, \mathrm{FO} 78 / 5398,371$

${ }^{29}$ PRO, FO 78/5398, 372. I owe thanks to İbrahim Şirin who drew my attention to the significance of Mark Sykes' travel. For the article drawing attention to this travel, see: İbrahim Şirin, "İngiliz Belgelerinde Kocaeli ve Çevresi," Uluslararası Gazi Akça Koca ve Kocaeli Tarihi Sempozyum Bildirileri, eds. Haluk Selvi \& M.Bilal Çelik (Kocaeli: Kocaeli Büyükşehir Belediyesi, 2015): 788.

${ }^{30} \mathrm{PRO}, \mathrm{FO} 78 / 5398,372$. As he acquired from a source that he claimed reliable, the rate of the population infected by the disease in Inebolu and other coastal towns was between $45 \%$ and 35\%. This rate reduced to $11 \%-13 \%$ from coastal towns to 9 miles to the inland. In Kastamonu, it fell to 5\% while it was 10\% - 8\% in the south of Kastamonu. The population affected by the disease rose to $80 \%$ approximately twenty years ago. PRO, FO 78/5398, Note I.
}

\author{
History Studies \\ www.historystudies.net
}


people of treatment, the situation became difficult to handle in the years ahead. The Ministry of the Interior sent a decree in 1907 stating that the people who caught diseases such as syphilis and hid their diseases would be reported to the government. ${ }^{31}$ Some people tried to hide their diseases, and they did not pay attention to the issue of disease.

As people did not coordinate with the government and local government refrain from engaging the traditional structure of the society was influential in fighting diseases impotently rather than lack of physical materials for treatment. Hence, the disease of syphilis continued being seen in Bolu and Kastamonu, where the disease was widely seen, and these places were remembered with syphilis for a while. ${ }^{32} \mathrm{He}$ commented that it was a misfortune to endure a disease outbreak as these people were superior to other Muslims in Asiatic Turkey almost in every topic from their industry to intelligence. ${ }^{33}$

Sykes underlined that among all the villages he visited, there was no place in which agriculture and pomiculture were so high compared to the population. Besides, people were generally constructed two-layered village houses about which Sykes told they were the best among the ones he saw before. ${ }^{34} \mathrm{He}$ admired the bridge that villagers constructed along with other buildings such as houses and a mosque praising the people's talent. ${ }^{35}$ From Karaviran, he headed for Kizllcahamam and he expounded his observations related to agriculture and industry. He told people cultivated rice in the watery islands and the strong dam all of which indicated the landowners' capacity and the industrial level. ${ }^{36}$

Drawing attention to the vacant houses in Kizllcahamam, Sykes mentioned they were rented in June, July, and August with the price of $£ 15-£ 10$. In and around Ankara, the people who suffered from rheumatism and skin diseases came there to benefit from the famous baths in the summertime. ${ }^{37}$ Sykes propounded that Say Hamam was also a bath, even hotter than Kizılcahamam adding there was no dweller here. Yet, he thought that there was a marketplace which testified the trade between Ankara and Kastamonu. ${ }^{38}$ In the intersection of several valleys, there was a vacant space that was looked around by a caretaker. Sykes presumed that the place turned out to be a marketplace by the merchants and paddlers on Thursdays. He marks that people although these places were far from the village, people from surrounding territories came

\footnotetext{
${ }^{31}$ BOA (Prime Ministry Ottoman Archives), Dahiliye Nezareti, Hukuk Müşavirliği Belgeleri, (DH. HMŞ.), 22/26, 22 Mart 1907 (1325.S.7).

${ }^{32}$ Ahmet Şerif, Anadolu'da Tanîn I, ed. Mehmed Çetin Börekçi (Ankara: Türk Tarih Kurumu Basımevi, 1999): 416; Ebru Boyar, "An İnconsequential Boil" or a "Terrible Disease"? Social Perceptions of and State Responses to Syphilis in the Late Ottoman Empire", Turkish Historical Review 2 (2011): 124. It is stated that syphilis began to spread Ottoman Empire from the entrance of Jews, who were exiled from Spain. In the $19^{\text {th }}$ century, the frequency of disease drastically rose due to the people who went to Russia through the Black Sea coast to starting bakeries after the Crimean War. Fatma Bulut, "Osmanlı'dan Cumhuriyet'e Tehlikeli Bir Miras: "Frengi," Tarih Okulu 3 (2009): 111-2; Erdem Yavuz, "Ahlat Kazasında Frengi (XIX.yy. Sonu-XX.yy. Baş1)”, Turkish Studies 12:26 (2017): 228. German General Baron von der Goltz, who served in the Turkish army in 1883, informed the government when the disease pervaded among the soldiers. A health commission held a meeting under the chairmanship of Doctor During Pasha, who specialized in dermatology and syphilis at Mekteb-i Tibbiye-i Şâhâne in the face of the seriousness of the situation. The precautions related to syphilis were discussed in the meeting. As Kastamonu and surrounding places had a high rate of syphilis infection, the fight against the disease started in these places. İnci Hot, "Ülkemizde Frengi Hastalığı ile Mücadele”, Türkiye Klinikleri Tip Etiği-Hukuku-Tarihi Dergisi 12: 1 (2004): 38.

${ }^{33}$ PRO, FO 78/5398, 372.

${ }^{34}$ PRO, FO 78/5398, 376.

${ }^{35}$ PRO, FO 78/5398, 376.

36 PRO, FO 78/5398, 377.

${ }^{37}$ PRO, FO 78/5398, 377.

${ }^{38}$ PRO, FO 78/5398, 378.
}

\author{
History Studies \\ www.historystudies.net
}


there for purchase and sale. Thus, this place, compared to other regions, provided a free shopping environment. ${ }^{39}$

While moving to Çerkeş over Işık Mountain, Sykes drew attention to the beauty of agricultural lands and panorama. He informed that Çerkeş was once a small village having twenty or thirty houses fifteen years ago; however, it had five hundred or more houses including several appealing khans, bathhouses, hotels, and two big state schools. He was offered to inspect the school where the pupils demonstrate their knowledge of mathematics and geography. ${ }^{40}$ The students welcomed the travelers warmly as understood from Sykes' notes. ${ }^{41}$ Thus, the region was developed economically, and its baths contributed to its potential of becoming a tourist destination.

The fundamental reason for the extent and the welfare of Çerkeş town was the mohair trade for Sykes. Almost all the products of the mohair were carried to Inebolu by wagons and carts. Sykes cited that people rarely used the railway in Ankara for carrying the products. He noted that people cultivated Ovacik valley, which had many villages and new khans, with caution and care. This situation signified increasing welfare and mobility in the town. ${ }^{42} \mathrm{He}$ identified that local landowners were also traders and they bought a variety of goods in Istanbul to sell them to their tenants and the neighboring villages in Kastamonu. He stated further that Çerkeş valley and the region surrounding it were open to profitable enterprises. For him, the transition to sea (over Inebolu) was not difficult and cheap. Including comprehensive opinions and observations on the economic facilities of the region, Sykes, as mentioned before, still defended a policy on behalf of Turks. He deemed pro-Turkish policies necessary for the protection of British interests. For this reason, he must have given a message to Britain by frequently displaying the economic potential of the region he visited to demonstrate that Britain's policies must have been on behalf of Turks.

\title{
2.2. Anthropological Inferences of Sykes from Ankara to Inebolu
}

One of the most striking parts of Sykes' travel was his creation of racial typology which illustrated and reflected Britain's imperialist and colonialist mentality. He virtually conducted an anthropological analysis of the Anatolian people. His examination represents the blend of highly discussed racial theories of the $19^{\text {th }}$ century with politics. In this period, Britain justified its hegemony and domination over anthropological and ethnographical discourse. The idea of Western superiority was shaped by the political and social consequence of the preconceptions of innate differences among the race, and genetics offered a certain scheme to politics while racial theories generated a legitimate infrastructure to it. ${ }^{43}$

\footnotetext{
${ }^{39}$ PRO, FO 78/5398, 378.

${ }^{40}$ These two state schools should be supposed to Klz Sanayi Mektebi and Ertuğrul İdadi Mektebi which were established in the time of Mehmet Enis Paşa's governorship.

${ }^{41}$ PRO, FO 78/5398, 379.

42 PRO, FO 78/5398, 382.

43 Andrew Heywood, Siyasi İdeolojiler: Bir Giriş, trans. Ahmet K. Bayram, Özgür Tüfekçi, Hüsamettin İnaç, Şeyma Akın \& Buğra Kalkan (Ankara: Adres Yayınları, 2010): 226-7. The economic, religious, and political interests came to the forefront in the West's encounter with different cultures. The idea of race, which emerged before the concept of race with the racial theories, was the root of discourses based on the categorization of races beginning at the end of the 18th century along with the antislavery movements. Moreover, the discussions about polygenesis and monogenesis oscillated between opposite thoughts and these discussions paved the way for a generation of the theoretical structure of the race concept which led to the dissidence in racial hybridity. For example, Kant defended the racial superiority of the West and categorized people according to their colour skin while Herder highlighted the diversity of people. In the 19th century, Blumenbach ve Göttingen School conducted experiments as to the measurement of head to predict certain characteristics and intelligence. Thus, these developments impacted the studies of race and scientific disciplines. Robert Bernasconi, Irk Kavramını Kim İcat Etti?: Felsefi Düşüncede Irk ve Irkçılık (Istanbul: Metis Yayınları, 2015): 45; 63.
}

\author{
History Studies \\ www.historystudies.net
}


Sykes found the appearance and the facial characteristics of the people and examined their features in four different typologies. He also added pictures of the typologies painted by $\mathrm{Mr}$. Sanders. ${ }^{44}$ In his notes, he composed a hybrid typology of the people:

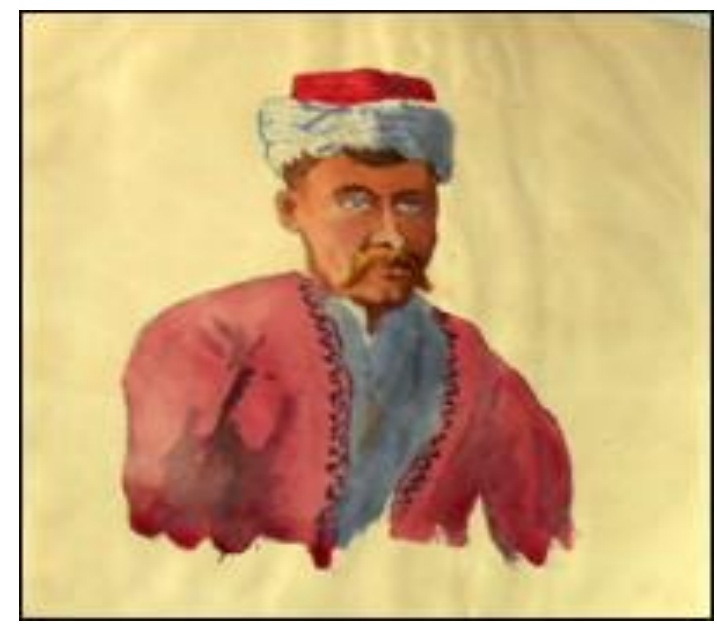

No. I. They were "a tall-faced man with a light brown beard, yellow mustache, small blue eyes." ${ }^{45} \mathrm{He}$ identified that these features resembled the improper facial characteristics of Western Europeans. As far as Sykes was concerned, this type was the most common one among the villagers. He explained that anthropologically, this type was different from the other types he had ever seen. He guessed that the invasion of Gauls in Delfi was responsible for this weird characteristic.

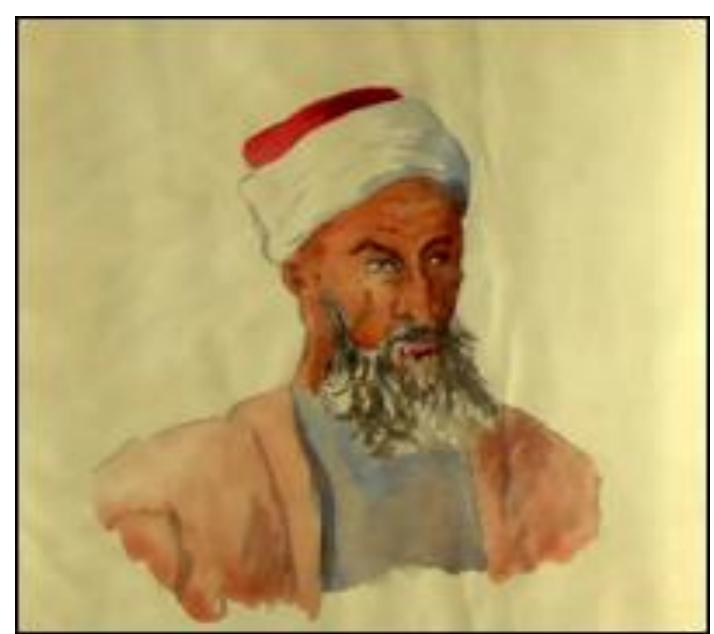

\footnotetext{
${ }^{44}$ Watercolor paintings in the travel notes of Mark Sykes were painted by Thomas Edmund Sandars (1877-1942). Sanders was one of the friends of Sykes from Cambridge University. He was known for the books such as The Book of Beats and The Book of Birds. Furthermore, Sykes and he published a book in 1904 called D'Ordel's Pantechnicon: A Universal Directory of the Mechanical Art of Manufacturing Illustrated Magazines, Intended as a Course of Learning for Future Writers, Containing an Account of the Advance of Literature in Modern Times in which they created a parody of some literary magazines and writers. He, as an agent, supported his writings with visuals apart from the paintings by taking photos of the panorama, people, and buildings.

${ }^{45}$ PRO, FO 78/5398, 373.
} 
No. II. He stated that the second type included the men who were "tall dark" having "full beard, dark eyebrows and eyelashes, hooked but rather bumpy nose, high forehead full lips" and "swallow complexion on the whole of a Semitic tendency." 46 He resembled them to a mixture of Arab and Jews with another race and claimed that this type had the coarse appearance of the Semitic race. Local administrators, notables, aghas, and property owners were among this type according to Sykes.

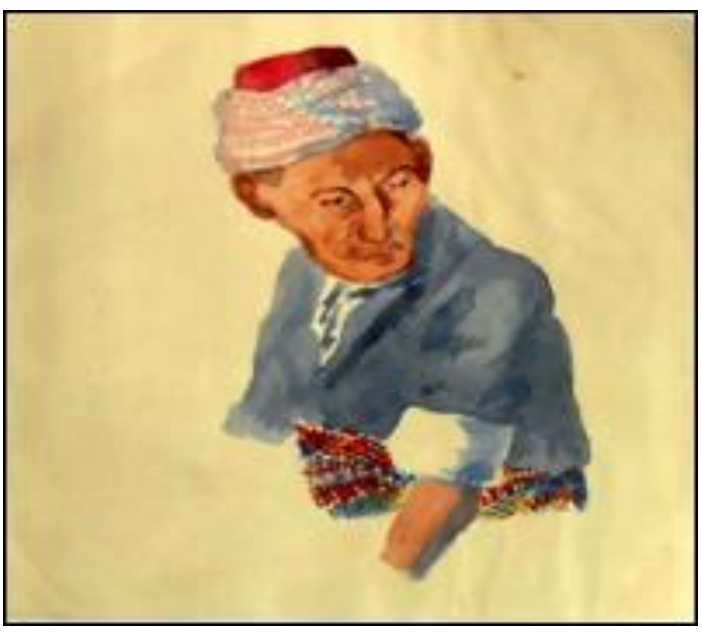

No. III. The third type was Mongolian. These men had "rather high cheekbones, to the beardless individual whose blunt nose, oblique eyes, peculiar jaw, and lank black hair." ${ }^{" 47} \mathrm{He}$ stated that the men in this type could have wrongly resembled Chinese. He even added the ratio of prevalence which was $1 / 20$ of the population. This type was not frequently encountered in every village.

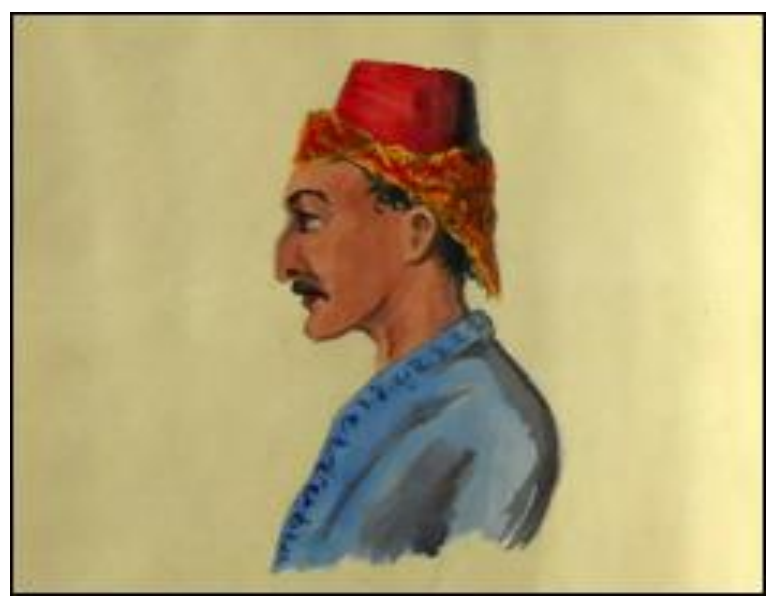

${ }^{46}$ PRO, FO 78/5398, 373-4.

${ }^{47}$ PRO, FO 78/5398, 374. 
No. IV. He stated that the fourth type was rare in Anatolia; however, it became more common by getting close to Kastamonu. He found this type particularly characteristic and impressive adding that he did not see this type in his previous travels. The men among this type were "slimly built" having "dark complexion, black crisp curly hair, high narrow forehead, small delicate mouth, Grecian chin, a curious small, hooked nose with a peculiar nostril." ${ }^{48} \mathrm{He}$ resembled this type to God and priest sculpture of Hittite which was said to be in Ivriz (Konya). ${ }^{49}$

After the categorization of four typologies, Sykes made certain inferences. In all the rural populations, there were examples of these four types according to his observations. When he made a comparison among the towns, there was a mixture of races from Istanbul to Baghdad; also, officers and merchants, who had different appearances, were everywhere. ${ }^{50}$ Considering the villages, these four types were observed, too. He underlined that although there were intermarriages, these types bore diverse features.

Considering the typology of Sykes, there were intermarriages which caused hybridity. Although there were marriages among the similar types, much more different types of people came into view. Sykes' typology and effort of categorizing people ostensibly reflected Britain's orientalist and hierarchical perspective in a period when the discussions on race were intense. Indeed, in his other travel to the Middle East, Sykes commented that Caucasian women were beautiful whereas men were simian, meaning ape. ${ }^{51}$ The approaches based on race became an outstanding discourse of the cultural distinctions in the formation process of Britain's nation and identity upon which Britain implemented its policies. ${ }^{52}$ Racial concerns among the British became much more visible and aggressive in the $19^{\text {th }}$ century and parallel with this, they penetrated the cultural structures in the East under the mission of civilization. ${ }^{53}$ For example, Britain provided Western-style education for Indians to civilize and develop them. Yet, it is obvious that the education provided by Christian missionaries was generated out of propagating the thoughts about Christianity. ${ }^{54}$ Besides, Britain established certain units which scrutinized and classified India according to its geographic, anthropologic, linguistic, economic, and demographic traits aside from changes in education, law, and bureaucracy after its domination. ${ }^{55}$ Under the mission of civilization, the emphasis was that the countries or states, which were labeled as noncivilized, were lack of advancing on their own. For this reason, the mission of "civilization" was legitimized, even, some thinkers of the period complied with the "holy" role of the West in civilizing the East. ${ }^{56}$ Having been a superficial anthropological practice, the

\footnotetext{
${ }^{48}$ PRO, FO 78/5398, 374-5.

49 Mark Sykes' likening the fourth type to God and priest sculpture of Hittite Monument is a good example of the discussion about the split or syncretism among the cultures. Syncretism is a concept to have been used in the recognition of identity in the $19^{\text {th }}$ century in an affirmative connotation; however, it is asserted that defining the resemblance between two cultures also draws attention to the differences which ended up with a cultural split. Peter Burke, Cultural Hybridity (Cornwall: Polity Press, 2009): 48; 91.

${ }^{50}$ PRO, FO 78/5398, 375.

${ }^{51}$ Mark Sykes, The Caliph's Last Heritage: A Short History of the Turkish Empire (London: Macmillan and Co.): 391.

52 Tony Ballantyne, Orientalism and Race: Aryanism in the British Empire (New York: Palgrave Macmillan, 2002): 190. The work of Ballantyne is salient to give clues about the political discourse of Britain in colonizing India. For a study that explains how Britain benefitted from disciplines such as anthropology and ethnography in nation-state construction see: Richard McMahon, The Races of Europe: Construction of National Identities in the Social Sciences, 1839-1939 (London: Palgrave Macmillan, 2016).

53 Barrington Moore, Diktatörlüğün ve Demokrasinin Toplumsal Kökenleri: Çăgdaş Dünyanın Yaratılmasında Soylunun ve Köylünün Rolü, trans. Şirin Tekeli \& Alaeddin Şenel (Ankara: İmge Kitabevi, 2012): 410-17. Kenneth Ballhatchet, Race, Sex and Class under the Raj: Impérial Attitudes and Policies and their Critics, 1793-1905 (New York: St. Martin's Press, 1980): p. 6.

${ }^{54}$ Belmekki Belkacem, "The Impact of British Rule on The Indian Muslim Community in The Nineteenth Century", ES: Revista de Filología Ínglesa 28 (2007): 38.

${ }_{55}^{5}$ Partha Chatterjee, Ulus ve Parçaları (Istanbul: İletişim Yayınları, 2002): 44.

${ }^{56}$ Zafer Toprak, Darwin'den Dersim'e: Cumhuriyet ve Antropoloji (Istanbul: Doğan Kitap, 2012): 538.
}

\author{
History Studies \\ www.historystudies.net
}


observation of Sykes is important. It illustrates the attempt of justification of Western superiority, in terms of superior and inferior dialectics, and dominance by categorizing people regarding their race. It also epitomizes the idea that imperialist thoughts advanced over the homogeneity and the racial hybridity was not approved. ${ }^{57}$ The interests shaped the approach towards the image of the other.

\title{
2.3. Political Observations of Sykes from Ankara to Inebolu
}

One of the most remarkable parts of his notes was his conversations with the local people about contemporary political issues. He stated that the people paid attention to the KitchenerCurzon incident ${ }^{58}$ in such a way that everybody asked his opinion about the matter. Besides, nobody talked about or commented on the German trade. The sole conversation involving the trade was that one merchant paid his respect to Sir W. Whittall. ${ }^{59}$ Sykes presented that people were not interested a lot in Russo-Japanese $\mathrm{War}^{60}$. Yet, people stated that Anglo-Japanese Alliance was "wonderful guile" and "astuteness" of the British diplomacy which aroused global admiration where Sykes thought "it was not hard to see that Britain loomed large in their eyes." This indicated that Britain had an important place and power in the eyes of the Anatolian people. It is striking that people did not have much comment to make on war; however, they knew the Kitchener-Curzon incident and they were keen on expressing their opinion. The information related to the people's perception of competent Britain requires particular attention. The addressee of the travel notes was the Foreign Office. Sykes, who was honorary attaché at that time, wanted to have an active role in politics and he made it happen through his knowledge of the Middle East. Thus, the intention of the writer should not be overlooked. Sykes might have strained the reality or exaggerated it. Taking the political conditions into account, Sykes must have given the message that Ottoman society was on the side of Britain by accentuating the complimentary comments of the people. It should be noted that the approach of Sykes to the Ottoman Empire was on behalf of the Turcophile policies right until the beginning of World War I. ${ }^{62}$

\footnotetext{
${ }^{57}$ Etienne Balibar \& Immanuel Wallerstein, Irk, Ulus, Sinıf: Belirsiz Kimlikler (Istanbul: Metis Yayınları, 2000): 31.

58 The dispute is related to the control over the military organization. When Lord Kitchener became the new Commander-in-Chief in India, he planned to centralize all military control on one hand by abolishing the dual military control. He considered that the present system was inefficient to lead a serious war. However, Lord Curzon tried to convince him to wait before making radical changes. Lord Curzon's effort did not work as Kitchener mentioned his opinions in the home government. Consequently, the power of the Military Member, the position of which Lord Curzon had, weakened in line with Lord Kitchener's proposal. Although Lord Curzon was opposed to this suggestion, he could not take the pressure and he was resigned. Stephen P. Cohen, "Issue, Role, and Personality: The KitchenerCurzon Dispute", Comparative Studies in Society and History 10: 3 (1968): 338-9.

${ }^{59}$ British Whittall family lived in Izmir, and Istanbul and they were engaged in international trade. Sir James Whittall, in the notes of Sykes, was a member of this family. He established the British Chamber of Commerce and he was occupied with a variety of commercial activities. For further information see F. Tanis \& K. M. Havik, "Spatial Stories of Izmir: A Narrative Study on the Influence of Trader Families on the Spatial Development of the Port City," In Bo: Ricerche e Progetti per il Territorio, la Città e l'Architettura, 11:15 (2020): 56-68; Osman Öndeş, Modalı Vitol Ailesi (Istanbul: Tarihçi Kitapevi, 2012).

${ }^{60}$ The first significant war of the $20^{\text {th }}$ century was the Russo-Japanese War (8 February $1904-5$ September 1905) in terms of the victory of an Eastern state over the Western power. For a study that examines the war in the diplomatic, military, and socio-cultural aspects see: David Wolff, Steven G. Marks, Bruce W. Menning, David Schimmelpenninck Van Der Oye, John W. Steinberg \& Yokote Shinji, The Russo-Japanese War in Global Perspective Vol. II (Leiden: Brill, 2007).

${ }^{61}$ PRO, FO 78/5398.

${ }^{62}$ Mark Sykes' Turcophile policies changed in the eve of World War I in line with Britain's will of economic and political domination over the Middle East, however, other reasons in his change of attitude need further examination. Celal Çıtak, Sir Mark Sykes Hayatı Ve Ortadoğu'daki İngiliz Politikasının Şekillenmesindeki Rolü, (Hacettepe Üniversitesi Atatürk İlkeleri ve İnkılap Tarihi Enstitüsü, Unpublished Ph.D.), Ankara, 1997, p. 51.
}

\author{
History Studies \\ www.historystudies.net
}


Besides, Sykes wrote that they had a calm journey during their route from Ankara to Kastomonu spotting only two weapons apart from the knives which were used for the daily task. As far as he observed, robbery, stabbing and manslaughter were not known to these people. Even Sykes quoted a memory, by distinguishing the difference between this region and other parts of the Middle East, to explain that the people there were not interested in weapons. When Sykes' Arabian servant, who was from Mosul, passed his weapon to hold to a villager, Sykes asked what happened if he gave the weapon to the one from Mosul. The Arabian servant replied, "By God, he would shoot me first, and then eat the pistol so that no one could get it from him." 63 The travel notes of Mark Sykes require attention because he used ironic language while he was transferring his thoughts. For instance, in this narration, he was not only pointed out the fact that people did not encounter a situation that required the use of a weapon but also, he reflected the preconceptions related to Turks and Arabians. Sykes felt prejudiced toward Arabians and his approach to Turks was much more moderate.

He also gave place to changing attitude of the Muslim population towards the Armenians. According to Sykes, in general, the Muslim population feared and hated Armenians. He added that they lived in peace though the incident took place in $1895-6^{64}$ and the people of Kastamonu did not have trouble with Armenians until the attempt of assassination against Abdülhamid II. ${ }^{65}$ Sykes mentioned, "the feeling has changed, and it would take very little trouble on the part of an official or a revolutionary to bring about a massacre." ${ }^{\prime 66}$ The comment of Sykes was of great import as it reflected the tension between Turks and Armenians. The breaking point of this change in attitude should be well examined. The attempt of assassination against Abdülhamid II seemed to be the last straw which was considered as a reaction against the symbol of power, although people endured the pre-existing disorders. As he continued his comments, he underlined that even a simple incident could cause massive ones considering the present situation. ${ }^{67}$

According to Sykes, Kastamonu became a "depot for exiles" for Druzes, Armenians, Turks, Young Turks, and Albanians. The governor himself was exiled there, too. ${ }^{68}$ Sykes found the governor as a kind-hearted and nice man who constantly had to deal with diverse documents and letters of which he vainly put effort not to approve. ${ }^{69}$ The governor of Kastamonu was not only dealing with paperwork and exiles. It was around the time when the Ottoman Empire abolished the Ağnam Tax which was levied to create new financial sources in 1904. Instead, the government levied a new tax, Hayvanat-l Ehliye Rüsumu, to collect tax for all the domestic. Besides, the government levied individual tax without distinguishing the villager or townsmen according to their income level. The decision of collecting new taxes led to uprisings in different

\footnotetext{
${ }^{63}$ PRO, FO 78/5398, 382.

${ }^{64}$ The occupation of Ottoman Bank in Galata, Istanbul took place in 1896 when the centre branch of the bank was captured by Armenians who were the members of Armenian Revolutionary Federation. For further information, see: Ethem Eldem, "26 Ağustos 1896 "Banka Vakası" ve 1896 "Ermeni olayları", Tarih ve Toplum Yeni Yaklaşımlar 5 (2007): 113-146; Fikrettin Yavuz, Osmanlı Devleti'nde Ermeni Terörü 1896 Osmanlı Bankası Baskını (Ankara: Türk Tarih Kurumu, 2015).

65 The attempt of Y1ldiz Assassination took place on 25 January 1905 after the Friday Prayer. When the prayer was over, the bomb was exploded killing 26 people and wounding 58. Abdülhamid II was safe and sound. This attempt at the assassination was undertaken by Armenian Revolutionary Federation. For further information see Houssine Alloul, Edhem Eldem \& Henk de Smaele, To Kill a Sultan A Transnational History of the Attempt on Abdülhamid II (1905), (Londra: Palgrave Macmillan, 2018); Vahdettin Engin, "Sultan II. Abdülhamid'e Düzenlenen Ermeni Suikasti ve Bu Sebeple Belçika ile Yaşanan Diplomatik Kriz,” Belleten 59/225 (1995): 413-428.

${ }^{66}$ PRO, FO 78/5398, 383.

${ }^{67}$ In one of his travel, Mark Sykes asserted that Turks did not have any excuse to slaughter Armenians; however, the massacres were still a prevailing policy in the East and until late in the West. Leslie, Mark Sykes, 91.

68 PRO, FO 78/5398, 383. The governor of Kastamonu, when Mark Sykes traveled there, was Mehmet Enis Paşa (Augustus 1987- 1 February 1906).

${ }^{69}$ PRO, FO 78/5398, 383.
}

\author{
History Studies \\ www.historystudies.net
}


parts of the Ottoman Empire. The first one happened in Kastamonu where the people were intensely exiled under the regime of Abdülhamid II. ${ }^{70}$ As a foreign observer, Sykes noted down his inferences related to the tension among the people. He remarked that Kastamonu was a beautiful and developing town; however, people rebuked the government for getting money from people under name of road construction though there was no development about it comparing the money that the government received. ${ }^{71}$

\title{
Conclusion
}

The knowledge production in the Middle East was extremely important for Britain both for having knowledge about the East and for realizing the political and economic interests particularly in the $19^{\text {th }}$ and $20^{\text {th }}$ centuries. This prioritized knowledge production which was fulfilled by the diverse institutions and agents of the time. Travel was a significant and efficient tool for knowledge production as it offers on the spot observation and interaction with the people.

Britain, at the same time, utilized different disciplines in accordance with his policies. As in the example of India, Britain generated its policies with the aim of "civilization" by reflecting his orientalist approach based on the superior-inferior relation. In this respect, there was a masculine West in the face of feminine, passive, and stable East. The West had the power to categorize the East in the frame of its envisagement, as seen in the travel of Mark Sykes. The West exerted to justify his deeds by the claim of anthropological examination carrying it to a scientific ground. It delineated its mentality regarding the Middle East.

The travel of Mark Sykes is critical in the sense that while it reveals the value of intelligence in knowledge production, he put forward his knowledge in the Middle East. It is apprehended that he knew the Middle Eastern geography well. He had conversations with people and listened to their comments related to political developments. Furthermore, he analyzed the people and categorized them as if he was an anthropologist. He mentioned the social and economic evolutions of the places he had visited. All the information he unveiled, helped him to create a holistic narration of the Middle East. He was carrying the mental patterns of British politics which necessitated to refrain from the protection of Ottoman integrity. Yet, Sykes's emphasis on economic development and creating a distinction between the Arabians and Turks must have been read as an effort of influencing the British policy on behalf of the Ottoman Empire. Sykes considered that Britain should have sustained its policy of Ottoman protection for the benefit of Britain. Thus, while his intelligence gathering is his reflection of political thought which was not in line with Britain's policy at that time, it was also part of Britain's imperialist mentality in terms of knowledge production.

All in all, the travel of Mark Sykes is worthy of attention in terms of its addressee, the way of Britain's implementation of imperialist policies, and revelation of anthropological layout in intelligence gathering. This short travel divulges different dimensions in terms of the Middle East in the eyes of both Mark Sykes and Britain, offering a precious context for understanding the political atmosphere of the period.

\footnotetext{
${ }^{70}$ Aykut Kansu, 1908 Devrimi (Istanbul: İletişim Yayınları, 2002): 39-40. Since high-ranking officials were exempt from the tax, the Kastamonu people did not want to pay individual tax. They wanted the governor of Kastamonu, who was the richest person in the town, to pay the tax instead of local people. Kansu, 1908, 40-41. In addition, the governor was claimed to be in cooperation with merchants and contractors. The officers' irregular payment was also increasing the tension. Thus, these motives caused the uprisings in 1906. Mehmet Serhat Y1lmaz, "II. Meşrutiyet Öncesi Kastamonu'da Bir Ayaklanma Girişimi (1906),” Karadeniz Araştırmaları 30 (2011): 127.

${ }^{71}$ PRO, FO 78/5398, 383.
}

\author{
History Studies \\ www.historystudies.net
}




\section{REFERENCES}

\section{Archival Sources}

\section{T.C. Cumhurbaşkanlığı Devlet Arşivleri Başkanlığı Osmanlı Arşivi}

BOA, Dahiliye Nezareti, Şifre Kalemi Belgeleri (DH. ŞFR.), 223/ 87, 13 Eylül 1897, (1315. R. 01).

BOA, Dahiliye Nezareti, Hukuk Müşavirliği Belgeleri, (DH. HMŞ.), 22/26, 22 Mart 1907 (1325.S.7).

The National Archive

TNA: PRO, FO Foreign Office Papers 78/5398, "From Angora to Inebolu”, 370-383.

\section{Turkish Historical Foundation}

Turkish Historical Foundation, Microfilm Archive (from Hull University Archive), The papers of Sir Mark Sykes, 1879- 1919 [microform]: with special reference to the Sykes-Picot Agreement and the Middle East, Microfilm 2, DDSY2/4 Foreign Affairs and Travel (18881919), 4/45 not dated, Draft Letter to 'Your Highness' from Mark Sykes about the condition of Turkey following the war with the Balkan Allies, with suggestions for improvement.

\section{Secondary Sources}

ALLOUL, Houssine, ELDEM, Edhem \& de SMAELE, Henk, To Kill a Sultan A Transnational History of the Attempt on Abdülhamid II (1905). Londra: Palgrave Macmillan, 2018.

BAĞÇECİ, Yahya. "İngiltere Parlamento Tutanaklarında 1876 Bulgar İsyanı." International Journal of Social Science 24 (2014): 211-235.

BAILEY, Frank Edgar. British Policy and Turkish Reform Movement: A Study of Anglo-Turkish Relations, 1826-1953. Cambridge: Harvard University Press, 1942.

BALIBAR, Etienne \& WALLERSTEIN, Immanuel. Irk, Ulus, Sinıf: Belirsiz Kimlikler. Istanbul: Metis Yayınları, 2000.

BALLANTYNE, Tony. Orientalism and Race: Aryanism in the British Empire. New York: Palgrave Macmillan, 2002.

BALLHATCHET, Kenneth. Race, Sex and Class under the Raj: Impérial Attitudes and Policies and their Critics, 1793-1905. New York: St. Martin's Press, 1980.

BELKACEM, Belmekki. "The Impact of British Rule on The Indian Muslim Community in The Nineteenth Century.” ES: Revista De Filología Inglesa 28 (2007): 27-46.

BERNASCONİ, Robert. Irk Kavramını Kim İcat Etti? Felsefi Düşüncede Irk ve Irkçılık. Istanbul: Metis Yayınları, 2015.

BOYAR, Ebru. "An Inconsequential Boil" or a "Terrible Disease"? Social Perceptions of and State Responses to Syphilis in the Late Ottoman Empire." Turkish Historical Review 2 (2011): 101-124.

BOZTEMUR, Recep. "Marx, Doğu Sorunu ve Oryantalizm.” in Oryantalizm I. Ankara, Doğu Batı Yayınları (2002): 135-150.

BULUT, Fatma. "Osmanlı'dan Cumhuriyet'e Tehlikeli Bir Miras: "Frengi." Tarih Okulu 3 (2009): 109-123.

BURKE, Peter. Cultural Hybridity. Cornwall: Polity Press, 2009. 
CHATTERJEE, Partha. Ulus ve Parçaları. Istanbul: İletişim Yayınları, 2002.

COHEN, Stephen P. "Issue, Role and Personality: The Kitchener-Curzon Dispute." Comparative Studies in Society and History 10: 3 (1968) 337-355.

ÇITAK, Celal. Sir Mark Sykes Hayatı Ve Ortadoğu'daki Ingiliz Politikasının Şekillenmesindeki Rolü, (Hacettepe Üniversitesi Atatürk İlkeleri ve İnkılap Tarihi Enstitüsü, Unpublished Ph.D), Ankara, 1997.

DJUVARA, Trandafir G. Türkiye’nin Paylaşılması Hakkında Yüz Proje, trans. Pulat Tacar, Gündoğan Yayınları, Ankara 1999.

EL GADDARI, Sara. "Hanmer Warrington and Imperial intelligence-gathering in Tripoli," in Diplomacy and Intelligence in the Nineteenth-Century Mediterranean World, eds. Mika Suonpää and Owain Wright, London, Bloombury Publishing, 2019, 37-56.

ELDEM, Ethem. "26 Ağustos 1896 "Banka Vakası” ve 1896 "Ermeni olayları.” Tarih ve Toplum Yeni Yaklaşımlar 5 (2007): 113-146.

ENGİN, Vahdettin. "Sultan II. Abdülhamid'e Düzenlenen Ermeni Suikasti ve Bu Sebeple Belçika ile Yaşanan Diplomatik Kriz.” Belleten 59:225 (1995): 413-428.

GLADSTONE, William Ewart. Bulgarian Horrors and the Question of the East, 1876. New York \& Montreal: Lovell, Adam, Wesson \& Company, 1876.

HERMAN, Michael. "Why Does Military Intelligence Matter?" Changing Character of War Seminar, Oxford. Accessed May 2021. 5http://www.nuffield.ox.ac.uk/OIG2/herman\%20 paper\%202007.pdf4.

HEYWOOD, Andrew. Siyasi İdeolojiler: Bir Giriş, trans. Ahmet K. Bayram, Özgür Tüfekçi, Hüsamettin İnaç, Şeyma Akın, Buğra Kalkan, Ankara: Adres Yayınları, 2010.

KANSU, Aykut. 1908 Devrimi. Istanbul: İletişim Yayınları, 2002.

KARACA, Taha Niyazi. "Dostluktan Çatışmaya: Osmanlı Dönemi Türk-İngiliz İlişkileri." Journal of Anglo-Turkish Relations 1:1 (2020): 11-32.

LESLIE, Shane. Mark Sykes: His Life and Letters. Londra: Cassell, 1923.

LEVI-STRAUSS, Claude. "Antropoloji." trans. Ümit Meriç, Sosyoloji Konferansı Dergisi 16 (1978): 102-128.

MCMAHON, Richard. The Races of Europe: Construction of National Identities in the Social Sciences, 1839-1939. London: Palgrave Macmillan, 2016.

MOORE, Barrington. Diktatörlüğün ve Demokrasinin Toplumsal Kökenleri: Çağdaş Dünyanın Yaratılmasında Soylunun ve Köylünün Rolü, trans. Şirin Tekeli \& Alaeddin Şenel. Ankara: İmge Kitabevi, 2012.

ÖNDEŞ, Osman. Modalı Vitol Ailesi. Istanbul: Tarihçi Kitapevi, 2012.

ÖZBEK, Nadir. Imparatorluğun Bedeli: Osmanlı Imparatorluğu'nda Gelir Vergisi 1839-1908. Istanbul: Boğaziçi Üniversitesi Yayınevi, 2015.

PAMUK, Şevket. Osmanlı-Türkiye İktisadi Tarihi 1500-1914. Istanbul: İletişim Yayınları, 2007.

REYHAN, Cenk. "Türk-Alman İlişkilerinin Tarihsel Arka Planı (1878-1914)." Belleten 69: 254 (2005): 217-266.

SECRET INTELLIGENCE SERVICE MI6. "Our History: Beginnings 1909.” Accessed May 1, 2021. https://www.sis.gov.uk/our-history.html. 
ŞERIF, Ahmet. Anadolu'da Tanîn I. ed. Mehmed Çetin Börekçi, Ankara: Türk Tarih Kurumu Basımevi, 1999.

ŞİRIN, İbrahim. "İngiliz Belgelerinde Kocaeli ve Çevresi." Uluslararası Gazi Akça Koca ve Kocaeli Tarihi Sempozyum Bildirileri, eds. Haluk Selvi-M.Bilal Çelik. Kocaeli: Kocaeli Büyükşsehir Belediyesi (2015): 787-793.

ŞİRIN, İbrahim. "Seyahatnâmelerin Sosyal Bilimlerde Kullanım Değeri: Seyahatnâme Metodolojisi Geliştirmenin Zorunluluğu", Yabancı Seyahatnamelerde Türkiye, eds. M. Çağatay Özdemir \& Yunus Emre Tekinsoy. Ankara: Türk Yurdu Yayınları (2016): 9-20.

STEELE, David. "Three British Prime Ministers and the Survival of the Ottoman Empire, 18551902." Middle Eastern Studies 50/1 (2014): 43-60.

SYKES, Christopher Simon. A Man Who Created the Middle East: A Story of Empire, Conflict and the Sykes-Picot Agreement. Londra: William Collins Books, 2016.

TANIS, F. \& HAVIK, K. M. "Spatial Stories of Izmir: A Narrative Study on the Influence of Trader Families on the Spatial Development of the Port City." In_Bo: Ricerche e Progetti per il Territorio, la Città e l'Architettura 11:15 (2020): 56-68.

TOPRAK, Zafer. Darwin'den Dersim'e: Cumhuriyet ve Antropoloji. Istanbul: Doğan Kitap, 2012.

TÜRKGELDİ, Ali Fuat. Maruf Similar. eds. Mehmet Kalpaklı \& Sina Akşin Somel. Ankara: Türk Tarih Kurumu, 2013.

WOLFF, David, Marks, Steven G., Menning, Bruce W., Van Der Oye, David Schimmelpenninck, Steinberg, John W. \& Shinji, Yokote. The Russo-Japanese War in Global Perspective Vol. II. Leiden: Brilll, 2007.

YAVUZ, Erdem. “Ahlat Kazasında Frengi (XIX.yy. Sonu-XX.yy. Baş1).” Turkish Studies 12:26 (2017): 223-236.

YAVUZ, Fikrettin. Osmanlı Devleti'nde Ermeni Terörü 1896 Osmanlı Bankası Baskını. Ankara: Türk Tarih Kurumu, 2015.

YILDIZELİ, Fahriye Begüm. "The Expansion of the British Empire in the Middle East After the Ottoman Heritage (1882-1923)." History Studies 10:6 (2018): 215-224.

YILMAZ, Mehmet Serhat. "II. Meşrutiyet Öncesi Kastamonu'da Bir Ayaklanma Girişimi (1906)." Karadeniz Araştırmaları 30 (2011): 123-142.

ZIEGLER, Paul R. Palmerston, British History in Perspective. New York: Palgrave Macmillan, 2003. 